\title{
Ring-Testing and Field-validation of a Terrestrial Model Ecosystem (TME) - An Instrument for Testing Potentially Harmful Substances: Effects of Carbendazim on Soil Microbial Parameters
}

\author{
J. PAULO SOUSA, ${ }^{1}$ JOSÉ M.L. RODRIGUES,${ }^{2}$ SUSANA LOUREIRO ${ }^{2}$ AMADEU M.V.M. \\ SOARES, ${ }^{2, *}$ SUSAN E. JONES, ${ }^{3}$ BERNHARD FÖRSTER ${ }^{4}$ AND CORNELIS A.M. VAN GESTEL ${ }^{5}$ \\ ${ }^{1}$ Instituto do Ambiente e Vida, Dep. Zoologia da Universidade de Coimbra, P3004-517 Coimbra, Portugal \\ ${ }^{2}$ Departamento de Biologia, Universidade de Aveiro, 3810-193 Aveiro, Portugal \\ ${ }^{3}$ University of Wales, School of Agricultural and Forestry Sciences, Bangor, Gwynedd LL57 2UW, Wales, UK \\ ${ }^{4}$ ECT Oekotoxikologie GmbH, Boettgerstrasse 2-14, D-65439 Floersheim am Main, Germany \\ ${ }^{5}$ Institute of Ecological Science, Vrije Universiteit, De Boelelaan 1085, 1081 HV Amsterdam, The Netherlands
}

Accepted 24 October 2002

\begin{abstract}
The effects of carbendazim on substrate induced respiration (SIR), dehydrogenase activity (DHA), phosphatase activity and thymidine incorporation by bacteria were evaluated in an experiment with an open intact Terrestrial Model Ecosystem (TME) and in a simultaneous field-validation study. Experiments were performed on four different European soils in Germany, The Netherlands, United Kingdom and Portugal. Data analysis focused on (i) detecting differences between experiments, especially in control values, (ii) checking similarity in data variability at each treatment level between experiments and (iii) analysing the resemblance of response to the model chemical in both experiments. Results obtained showed that control values from TME experiments were similar to those obtained on the respective field site, in most of the comparisons made for SIR, DHA and thymidine incorporation. Phosphatase activity revealed more differences, but values of both experiments had the same order of magnitude. At least part of the variation could be explained from the correlation of the microbial parameters with soil moisture content. Comparisons on data variability also revealed the absence of significant differences between experiments in all parameters in most cases, indicating that TMEs were able to represent the spatial variability found in the field. Effects of carbendazim, when occurring, were observed at treatment levels exceeding the highest recommended application rate of $0.36 \mathrm{~kg}$ a.i./ha. Effects on SIR and DHA were observed early in time, but effects on phosphatase activity and thymidine incorporation rate were found 8 or 16 weeks after chemical application. These effects were mild, and rarely a 50\% inhibition on any of these parameters was seen at carbendazim dosages up to $87.5 \mathrm{~kg}$ a.i./ha. The response to the model chemical in TMEs and field plots was similar in most cases. These results give promising prospects for the use of TMEs as an integrative tool in higher tier levels of different assessment schemes.
\end{abstract}

Keywords: terrestrial model ecosystem; mesocosm; field study; microbial parameters; carbendazim

\section{Introduction}

*To whom correspondence should be addressed:

Tel.: +351-234370779; Fax: +351-234426408;

E-mail: asoares@bio.ua.pt

It is widely recognized that chemicals may exert effects at the ecosystem level not fully predicted by 
single species toxicity tests. Therefore, the collection of data at higher levels of biological organization is required by different Environmental Risk Assessment (ERA) schemes, although the methodologies for their acquisition are not yet standardized or validated. Mesocosm studies play here an important role. Terrestrial Model Ecosystems (TMEs) were developed for linking laboratory and field data by studying soil columns under controlled conditions in the laboratory and may be used to assess effects both at structural and functional levels (Morgan and Knacker, 1994). Moreover TMEs can be used as higher tier level tools in assessment schemes under European chemical legislation, particularly if concern persists after low tier testing or if more information of effects is needed (Weyers et al., 2004). Integrated in a broader research project (see Knacker et al., 2004), this paper presents the results on the microbial parameters obtained from two experiments, a mesocosm study using TMEs and a parallel fieldvalidation study both using carbendazim as model chemical.

Microorganisms are considered keystone players in the soil system, mediating numerous functional processes related mainly with organic matter decomposition and nutrient cycling, thus contributing to the maintenance of soil health (Torstensson et al., 1998). This fact makes them sensitive indicators of soil disturbance (Sparling, 1997), being widely used in various situations (e.g., soil management practices and soil pollution). Most of the microbial parameters used are based on the determination of microbial biomass or on the measurement of end products of their metabolic activity $\left(\mathrm{CO}_{2}\right.$ production and enzymes).

Despite the variability of results found in the literature, it is known that several xenobiotics, especially heavy metals, may cause a reduction in soil microbial parameters (Giller et al., 1998). However, a strong reduction of enzyme activity, microbial respiration or microbial biomass is observed when pesticides are used in higher dosages than the recommended field application rates (Dzantor and Felsot, 1991; Perucci and Scarponi, 1994; Felsot and Dzantor, 1995; Dick, 1997; Perucci et al., 2000). At lower dosages, the effects may be transient (Ismail et al., 1995, 1996; Tu, 1995; Hart and Brookes, 1996a), and frequently a stimulation of microbial activity is reported
(Harden et al., 1993; Hart and Brookes, 1996b), what could be associated to the microbial degradation of the compounds or to changes in the nutrient status of the system. With regard to carbendazim and related substances, they are known to strongly disrupt mycorrhiza functioning (Kling and Jakobsen, 1997; Schweiger and Jakobsen, 1998) and inhibit bacterial and yeast processes (Chiba et al., 1987; Chalam et al., 1996). However, in most of the literature no significant reduction in soil respiration, microbial biomass or enzyme activity was found in treated soils (Helweg, 1973; Van Faassen, 1974; Adema et al., 1984; Li and Nelson, 1985; Eder et al., 1992; Harden et al., 1993; Förster et al., 1996; Vink and Van Straalen, 1999). By contrast, an increase in microbial activity or microbial numbers was observed in some studies (Peeples, 1974; Wainwright and Pugh, 1974).

The overall aim of this project was to validate the use of TMEs within a range of soil types (Knacker et al., 2004). In this paper we analyse and compare the results of several microbial parameters measured on the TMEs with those obtained during simultaneous field studies. Here we compare data variability between experiments and the type of response obtained in each experiment induced by the model chemical used. In particular we analyse if (i) there are any differences in values between experiments, especially in control measurements, (ii) if the variability of data inside each treatment level is similar among experiments and (iii) if TMEs can give a similar response to the field assays in terms of effects of carbendazim.

\section{Materials and methods}

Four different soils were used (see below) and the following microbial parameters were selected: substrate induced respiration (SIR), dehydrogenase activity (DHA), phosphatase activity and thymidine incorporation. SIR is used to estimate microbial biomass and is widely used to assess several types of effects on microbial communities (Sparling, 1997), while the two selected enzymes are probably the most well studied enzymes when assessing effects of pesticides in soils (Dick, 1997). Dehydrogenase is an endocellular enzyme involved in cell metabolism and is used as an indicator of 
physiologically active organisms (Rossel et al., 1997). Phosphatase is an exocellular enzyme involved in the hydrolysis of organically bound phosphate, resulting in a release of inorganic phosphate (Megharaj et al., 1999; Acosta-Martinez and Tabatabai, 2000). Thymidine incorporation is used to estimate the growth rate of soil bacteria by measuring $\left[{ }^{3} \mathrm{H}\right]$ thymidine $\left(\left[{ }^{3} \mathrm{H}\right] \mathrm{T}\right)$ incorporation into cellular DNA (Christensen and Christensen, 1995).

Three experiments were conducted. In 1998 a TME pre-test was performed to gain experience with the equipment and methodologies. This was followed in 1999 by the TME ring-test and a fieldvalidation study.

\section{Soil types used and site characterization}

Four different European soils were used. The selection of sites was based on the Euro-soils concept (Kuhnt and Muntau, 1994) and experiments were performed in different countries (Germany, The Netherlands, United Kingdom and Portugal). At each location a field site of approximately $2500 \mathrm{~m}^{2}$ was selected. The German site is located in an agricultural area in the region of Frankfurt A.M. This site is surrounded by arable land and pastures, but is managed as a grassland for more than 50 years. The soil was fertilized annually $(200 \mathrm{~kg} /$ ha of NPK fertilizer) until 1998. The field site in The Netherlands belongs to the facilities of Wageningen University, also in an agricultural area. Before being used for this study the site was used for grazing and cropping, with annual applications of fertilizer. The UK field site belongs to the field station of the University of Wales, Bangor, and it has been used mainly for silage and grazing and submitted to a double annual fertilization ( $\mathrm{N}$ in spring and NPK in autumn). In 1995 this site was limed and treated with slurry. The Portuguese site is located on the grounds of Coimbra Agricultural School, near the Mondego River. The area is used for experimental studies, mainly with maize crops, and is surrounded by several drainage channels emptying into the main river. The site was separated from maize fields by wide boundaries and was not used for cultivation since 1996. During the field-validation study a drainage channel was built at two sides of the site to avoid flooding. For a complete description of the sites it can be referred to Knacker et al. (2004).

At each site, several soil samples were collected to make a pedological characterization. At each sampling point, one sample from the first $5 \mathrm{~cm}$ and another from 5 to $15 \mathrm{~cm}$ were collected. Samples were mixed and parameters were measured by the University of Wales according to ISO guidelines (Table 1).

\section{Soil preparation and soil core extraction (TME pre-test and TME ring-test)}

Before the extraction of soil cores, used in the TME pre-test (Spring 1998) and in the TME ringtest (Spring 1999), sites were prepared as follows. At the German, Dutch and UK sites the vegetation was cut to a height of $2 \mathrm{~cm}$ and certain parcels of the site were selected for core extraction. At the Portuguese site, weeds were cut and the soil was ploughed twice homogenizing the upper $20 \mathrm{~cm}$ of soil.

Soil cores (40 cm long and $17.5 \mathrm{~cm}$ diameter) were encased in a high density polyethylene tube, forming a single TME. Their extraction was done using a special device made of stainless steel and with the help of a hydraulic excavator, used to force the extractor into the soil and to pull it out. During the procedure special care was taken to avoid soil compaction; cores where the soil surface was at a lower level than the surrounded soil were discarded. After extraction, the bottom of the soil cores was closed with a fine gauze and a high density polyethylene plate, used as a protection during transportation and to collect leachate during the experiments. The extraction was done $2-$ 4 weeks before the application of the model chemical.

TME installation and maintenance (TME pre-test and TME ring-test)

In the laboratory TMEs were placed in special carts designed for this purpose. Each cart was connected to a cooling system allowing the maintenance of the soil temperature around $12 \pm 2{ }^{\circ} \mathrm{C}$. The collection of leachate in each TME was possible by connecting the bottom plate to a polyethylene bottle containing a small amount of concentrated $\mathrm{HCl}$. Light intensity and regime, air 
Table 1. Pedological characterization $(0-15 \mathrm{~cm}$ layer) and land use of the field sites used in TME pre-test, TME ring-test and field validation study

\begin{tabular}{|c|c|c|c|c|}
\hline & $\begin{array}{l}\text { Flöersheim } \\
\text { (Germany) }\end{array}$ & $\begin{array}{l}\text { Amsterdam } \\
\text { (The Netherlands) }\end{array}$ & Bangor (UK) & Coimbra (Portugal) \\
\hline Soil type & Fluvisol (brown earth) & Podzol & Fluvisol (brown earth) & Fluvisol (brown earth) \\
\hline Textural class & Silty clay loam & Sandy loam & Loam & Silty loam \\
\hline $\mathrm{pH}(\mathrm{KCl})$ & $5.3-5.9$ & $4.8-5.1$ & $5.8-6.6$ & $6.4-7.1$ \\
\hline Total C (\%) & 3.0 & 2.6 & 3.5 & 2.0 \\
\hline Total N (\%) & 0.28 & 0.21 & 0.32 & 0.19 \\
\hline $\mathrm{CaCO}_{3}(\%)$ & 1.5 & 1.7 & 1.6 & 0.2 \\
\hline $\mathrm{CEC}(\mathrm{cmol} / \mathrm{kg})^{\mathrm{a}}$ & 24.3 & 8.5 & 17.6 & 24.3 \\
\hline Organic matter $(\%)^{\mathrm{b}}$ & 5.2 & 4.5 & 6.1 & 3.4 \\
\hline Sand $(\%)$ & 13.5 & 80.8 & 47.5 & 13.2 \\
\hline Silt $(\%)$ & 41.8 & 6.1 & 23.5 & 55.0 \\
\hline Clay $(\%)$ & 36.5 & 7.9 & 20.5 & 24.7 \\
\hline $\begin{array}{l}\text { Bulk density }\left(\mathrm{g} \mathrm{cm}^{-3}\right) \\
(0-5 \mathrm{~cm} \text { layer })\end{array}$ & 1.0 & 1.25 & 1.34 & 1.05 \\
\hline Water holding capacity (\%) & 93.9 & 37.3 & 70.0 & 75.0 \\
\hline Porosity (\%) & 63.3 & 52.8 & 49.4 & 60.4 \\
\hline Site use & Grassland & Grassland & Grassland & Arable land \\
\hline
\end{tabular}

${ }^{\text {a }}$ CEC cation exchange capacity.

${ }^{\mathrm{b}}$ Calculated by multiplying total $\mathrm{C}$ by 1.724 .

temperature and air moisture were controlled. The air temperature was $23 \pm 5{ }^{\circ} \mathrm{C}$, the relative humidity $50-80 \%$, the day/night cycle $16 / 8 \mathrm{~h}$ and the illumination 8,000-12,000 lux.

During the adaptation period and during the performance of the tests, TMEs were irrigated with artificial rainwater, modified after Velthorst (1993), 3 or 4 times a week using rain-heads. The amount of water used each week was calculated based not only on the average rainfall for each site, but also on the type of soil, type and stage of vegetation present and amount of leachate produced. Thus the amount of water used was not the same for each laboratory, and also changed during the course of the experiments (in this case an increase in the amount of rain was necessary to overcome the greater volume of the vegetation). These adjustments were done mainly in the TME ring-test, based on the results obtained in the TME pre-test. All this effort was done to maintain a constant moisture condition in the soil, because this factor may strongly influence several measured parameters such as microbial activity and nutrient contents.

In Coimbra, 1 week before the application of the test substance, weed detritus (especially roots) was removed and the soil in each TME was prepared to receive three specimen of Brassica rapa, selected according to the OECD protocol no. 208 (OECD , 1984). The specimen were planted as germinated seeds in small holes with $2-3 \mathrm{~cm}$ depth and covered with a small amount of soil.

Before application of the model chemical, TMEs that showed functional problems (no leachate or slow leaching) or having dead plants (in case of Coimbra TMEs) were discarded.

Test design and chemical application (TME pre-test and TME ring-test)

The model chemical was applied as a commercial formulation Derosal (a.i. $360 \mathrm{~g}$ carbendazim $\mathrm{1}^{-1}$ ). Proper amounts of Derosal were mixed with distilled water up to a volume of $50 \mathrm{ml}$. This amount was applied evenly on the TME with the help of a pipette and afterwards each TME was irrigated with $150 \mathrm{ml}$ of artificial rainwater.

In the TME pre-test a control (T0) plus four treatment levels (T1-T4) were chosen, including the highest recommended field rate $(0.36 \mathrm{~kg}$ a.i. ha) and the other treatments spaced by a factor of six: $2.16,12.96$ and $77.96 \mathrm{~kg}$ a.i./ha. Samples were collected $1,4,8$ and 16 weeks after chemical ap- 
plication. Six replicates from the control and three replicates from each treatment level per sampling time were sampled.

Based on the experience obtained with the TME pre-test, a different test design was adopted for the TME ring-test. So, in addition to the control (T0), six treatment levels were chosen (T1-T6). In this case a spacing factor of three was used, and treatment levels amounted 0.36, 1.08, 3.24, 9.72, 29.16 and $87.48 \mathrm{~kg}$ a.i./ha. The sampling scheme was also modified, according to the following procedure. One week after chemical application only $\mathrm{T} 0, \mathrm{~T} 1$ and $\mathrm{T} 6$ treatments were sampled. Eight and sixteen weeks after chemical application samples were collected from all treatments. At every sampling point, six controls and four replicates for each treatment level were sampled. Both on the TME pre-test and the TME ring-test the assignment of treatments to the TMEs was completely randomized.

\section{Field-validation study}

The field-validation study was performed in 1999 in parallel with the TME ring-test, with a time lag interval of only 1 or 2 weeks. The soil was prepared as described earlier. At the Coimbra site, after ploughing, Brassica rapa was planted as seeds in defined rows along the area.

After soil preparation, 30 squares $(5 \mathrm{~m} \times 5 \mathrm{~m})$ were marked at each test site. To avoid cross contamination each square was separated from its neighbours by a boundary of $2 \mathrm{~m}$. The test design and sampling scheme were the same as in the TME ring-test, therefore 6 squares were assigned to controls (T0) and groups of 4 squares were assigned to each of the six treatment levels (T1-T6). The model chemical was applied using a PL1 sprayer equipped with ten flat ray spray nozzles commonly used in agriculture. With the exception of the highest treatment (T6), where a 61 solution was used, the proper amount of Derosal was dissolved in 31 of water and this solution was sprayed over each square. Immediately afterwards each square was irrigated with 20-30 1 water to wash the chemical out of the vegetation. At the Coimbra site, during the test the whole area was irrigated daily with river water (3.2 $\mathrm{mm} /$ day).

\section{Sampling, soil processing and measurement of micro- bial parameters}

From each TME, after sampling for some effect parameters (see other papers on this issue), the remaining top soil layer $(0-5 \mathrm{~cm})$ was removed, homogenized, sieved $(2 \mathrm{~mm})$ and divided into several aliquots for analysis. Some of these were used to determine soil moisture content (dried at $105^{\circ} \mathrm{C}$ overnight $)$, soil $\mathrm{pH}(1 \mathrm{M} \mathrm{KCl})$ and the selected microbial parameters. In the field, sampling of the top soil layer $(0-5 \mathrm{~cm})$ was done using a split-corer $(5 \mathrm{~cm}$ diameter). From each replicate plot several samples were taken and pooled afterwards. This soil received the same treatment as described above.

When possible microbial analyses were performed immediately after sampling. Otherwise samples were stored at $0-4{ }^{\circ} \mathrm{C}$ until analysis, if determinations were to be performed within 23 weeks, or at $-20{ }^{\circ} \mathrm{C}$ if samples had to wait more than 1 month. Frozen storage only happened in the case of SIR measurements; according to Stenberg et al. (1998) this process does not affect SIR measurements. Before analysis, frozen samples were thawed at $4{ }^{\circ} \mathrm{C}$ during 5-7 days to avoid rapid changes in temperature.

SIR was measured using an infrared gas analyser coupled to a thermal flow meter and using ambient air as reference air (Heinemeyer et al., 1989). Before measurement, the moisture content of samples was adjusted to $50 \%$ of the water holding capacity (Beck et al., 1996). Each sample (50 g soil wet weight) was then left to rest for $24 \mathrm{~h}$, at $22{ }^{\circ} \mathrm{C}$, in plastic vessels with cotton plugs. This procedure is important for grassland and agricultural soils, because during this adaptation period fast degradable carbon compounds are decomposed. In a previous trial with the four soil types used, it was observed that water loss during this period (on average less than 5\%) did not influence the outcome of the measurement. After this period samples were introduced into the respirometer and $\mathrm{CO}_{2}$ production was measured for 4-6 h. Samples were then amended with $4,000 \mathrm{mg} / \mathrm{kg}$ glucose (in a glucose:talcum mixture) that was carefully mixed in with the soil. The amount of glucose added was based on previous trials with the four soils where different doses of glucose were assayed. $\mathrm{CO}_{2}$ production was recorded during at least $8 \mathrm{~h}$. 
Measurements were done at $22{ }^{\circ} \mathrm{C}$ and samples were aerated with a continuous flow of ambient air. After the measurements, moisture content of the samples was determined, and this value was used to calculate the SIR value, expressed as $\mu \mathrm{g}$ $\mathrm{CO}_{2} / \mathrm{g}$ soil $\mathrm{DW} / \mathrm{h}$.

DHA was measured using the method of Öhlinger (1996). For each sample $5 \mathrm{~g}$ of soil were placed in four Erlenmeyer flasks. Three of them were suspended in $5 \mathrm{ml}$ of a TTC (Triphenyltetrazolium chloride - Sigma) solution prepared with $0.1 \mathrm{M}$ Tris buffer (the concentration of TTC and the $\mathrm{pH}$ of the buffer were adjusted according to the soil type). Buffer $(5 \mathrm{ml})$ was added only in the fourth Erlenmeyer. Vessels were sealed and incubated for $24 \mathrm{~h}$, at $40{ }^{\circ} \mathrm{C}$. After this period the formed TPF (Triphenyl formazan) was extracted using $25 \mathrm{ml}$ of acetone and put into an orbital shaker for $2 \mathrm{~h}$, in the dark. Afterwards suspensions were filtered and TPF in the filtrates was determined photometrically, at $546 \mathrm{~nm}$, within $1 \mathrm{~h}$. TPF concentration was calculated using a calibration curve made with a standard solution of TPF (Sigma; $0.1 \mathrm{mg} / \mathrm{ml}$ ) after subtracting the absorbance of the fourth to the average absorbance from the other three vessels. Results were expressed in $\mu \mathrm{g} \mathrm{TPF} / \mathrm{g}$ soil $\mathrm{DW} / \mathrm{h}$.

Phosphatase activity was only measured in samples from the TME ring-test and field-validation study, using the method of Margesin (1996) adapted to a microplate reader. Soil samples (1 g) were mixed with $115 \mathrm{mM}$ p-nitrophenyl phosphate (Sigma; $1 \mathrm{ml}$ ) and a buffer solution (4 ml), and incubated for $2 \mathrm{~h}$, at $35^{\circ} \mathrm{C}$. For soils with a $\mathrm{pH}$ value between 6 and 7 (Amsterdam, Bangor and Flörsheim soils) a Modified Universal Buffer (MUB) was used; for Coimbra soil ( $\mathrm{pH}$ value between 4 and 6) an acetate buffer solution was used. After this period $0.5 \mathrm{M} \mathrm{CaCl}_{2}(1 \mathrm{ml})$ and $4 \mathrm{ml}$ of another buffer solution was added $(0.5 \mathrm{M}$ $\mathrm{NaOH}$ for soil $\mathrm{pH}$ between 6 and 7, and THAM buffer, for soil $\mathrm{pH}$ between 4 and 6). This was then mixed in a vortex for $10 \mathrm{~s}$ and centrifuged for $4 \mathrm{~min}$, at 4,000 rpm. The $p$-nitrophenol $(p \mathrm{NP})$ in the filtrate was determined using a microplate reader at $405 \mathrm{~nm}$. The $p N P$ concentration was calculated using a calibration curve made with a standard solution of $p$ NP (Sigma; $20 \mu \mathrm{g} / \mathrm{ml}$ ). Results were expressed in $\mu \mathrm{g} p \mathrm{NP} / \mathrm{g}$ soil $\mathrm{DW} / \mathrm{h}$.
Thymidine incorporation was only measured in samples taken after 4 and 16 weeks in the TME pre-test, and after 16 weeks in the TME ring-test and field-validation study. The homogenizationcentrifugation method of Bååth (1992) was used to measure thymidine incorporation in the pre-test. This method was based on a rapid bacterial cell extraction from soil followed by radiolabelling and extraction, but was found to produce a very high sample variation. Thus, in the TME ring-test and field-validation study, the tritiated thymidine $\left(\left[{ }^{3} \mathrm{H}\right] \mathrm{T}\right)$ incorporation assay of Christensen and Christensen (1995) was used instead to measure bacterial growth rates. This technique used soil samples radiolabelled as slurries, followed by a short incubation and recovery of labelled cells by membrane filtration. All reagents used in the incubation steps in this method were sterilized by filtration $(0.22 \mu \mathrm{m}$ mesh $)$ on the day of use, or autoclaved and stored at $4{ }^{\circ} \mathrm{C}$. Unless stated otherwise, reagents and samples were equilibrated to room temperature $\left(24^{\circ} \mathrm{C}\right)$. To prepare labelled DNA, $0.5 \mathrm{ml}$ aliquots of $\left[{ }^{3} \mathrm{H}\right] \mathrm{T}$ labelling solution (comprising $300 \mu \mathrm{l}\left[{ }^{3} \mathrm{H}\right] \mathrm{T}$ (1mCi/ml, Amersham) and $20 \mu \mathrm{l}$ unlabelled thymidine $0.1 \mathrm{mM}$ ), made up to $50 \mathrm{ml}$ with sterile water were mixed in with $50 \mathrm{mg}$ (wet weight) of soil samples in centrifuge tubes. Following exactly $15 \mathrm{~min}$ of incubation, $0.5 \mathrm{ml}$ of $20 \%$ formalin was added to stop the reaction. After approximately $30 \mathrm{~min}, 1 \mathrm{ml}$ of water was added to each tube to avoid disintegration of DNA and the tubes were then frozen at $-20{ }^{\circ} \mathrm{C}$ until processing. Blanks were prepared by adding $0.5 \mathrm{ml}$ formalin (20\%) $15 \mathrm{~min}$ before addition of the $\left[{ }^{3} \mathrm{H}\right] \mathrm{T}$ labelling solution to replicate soil samples and then treated as before, omitting a further addition of formalin. To extract labelled bacterial DNA, $5 \mathrm{ml}$ of $\mathrm{NaOH}(0.6 \mathrm{M})$ was added to each tube, mixed and incubated at $60^{\circ} \mathrm{C}$, for $1 \mathrm{~h}$. Following a $15 \mathrm{~min}$ rest period at ambient temperature, the tubes were centrifuged at $10,000 \mathrm{~g}$ for $20 \mathrm{~min}$ and the supernatants transferred to $100 \mathrm{ml}$ flasks. Distilled water $(50 \mathrm{ml})$ was added to each flask, which was then chilled in an ice/salt bath and acidified with $1 \mathrm{M} \mathrm{HCl}$ to bring the $\mathrm{pH}$ to below 2.0. To recover labelled cells, membrane filtration (cellulose acetate filters, Whatman, $0.45 \mu \mathrm{m}$, $25 \mathrm{~mm}$ ) was used, followed by rinsing each filter 5 times with $3 \mathrm{ml}$ of ice-cold $1 \%$ trichloroacetic acid solution. Filters were placed in scintillation vials, 
digested with $1 \mathrm{ml}$ Scintran (Merck), and $9 \mathrm{ml}$ of scintillation cocktail was added. Samples were stored overnight (minimum) to reduce chemiluminescence before counting the ${ }^{3} \mathrm{H}$ activity. The $\left[{ }^{3} \mathrm{H}\right]$ thymidine incorporation rate $\left(\mathrm{pmol}\left[{ }^{3} \mathrm{H}\right] \mathrm{T} / \mathrm{g}\right.$ soil $\mathrm{DW} / \mathrm{h})$ was calculated as: Rate $=(0.06 \mathrm{dpm}) /$ (mg dry wt.), where dpm denoted counts in the ${ }^{3} \mathrm{H}$ channel corrected for counting efficiency, and $\mathrm{mg}$ dry wt. was the (corrected) weight of the sample. This calculation was valid under conditions of 30 $\mathrm{Ci} \mathrm{mmol}\left(=6.66 \times 10^{16} \mathrm{dpm} \mathrm{mol}^{-1}\right)$ specific activity of $\left[{ }^{3} \mathrm{H}\right] \mathrm{T}$ and a labelling period of $15 \mathrm{~min}$ (Christensen and Christensen, 1995).

\section{Statistical analysis}

Results from the different experiments were analysed using different statistical procedures according to the questions addressed. To assess possible effects of the chemical, $\mathrm{EC}_{20}$ and $\mathrm{EC}_{50}$ values were calculated using a logistic model (Haanstra et al., 1985). NOEC values were calculated using an ANOVA followed by the Dunnett comparison test (Zar, 1996). Differences between results from the TME ring-test and the field-validation study were compared by a Student $t$-test, and differences in control values between soils were compared using an ANOVA (followed, when needed, by a Newman-Keuls test). Prior to all tests data was checked for normality and homogeneity of variances using the Kolmogorov-Smirnof, $F$ and Bartlett tests, respectively. When these assumptions were not met, data were transformed accordingly. Differences in data variability between these two experiments were analysed comparing the coefficients of variation (CVs) by a $Z$-test. The Pearson correlation coefficient was used to analyse the relation between SIR and enzyme activities and moisture content (Zar, 1996).

\section{Results}

\section{TME pre-test}

Results from SIR measurements show that, despite the feeble tendency to induce lower values at the highest treatment levels on weeks 4,8 and 16, carbendazim had no significant effect in the Bangor soil at none of the doses tested in any of the sampling times (ANOVA with $p>0.05$ for all times). In the Coimbra soil the response was not constant through time. Carbendazim induced a visible but non-significant $\left(F_{4,12}=0.11, p>0.05\right)$ decrease in SIR values at the highest concentration at week 16, and induced an increased respiration at weeks 1 and 4 . This latter effect was significant with the two highest concentrations being higher than the control $\left(q_{13,5}=4.951, p<0.05\right.$ for T3 and $q_{13,5}=4.501, p<0.05$ for T4).

In the Flörsheim and Amsterdam soils, SIR showed a visible tendency to decrease with increasing doses of carbendazim, especially from week 4 onwards. However, these effects are apparent; it was observed that to an increase of carbendazim dosage corresponded a decrease in soil moisture content, resulting in a strong correlation between these two parameters (Table 2). Moreover, when soil moisture content was treated as a covariable, previous significant differences found in the ANOVA (in Flörsheim soil on week 8 and in Amsterdam soil on week 16) were eliminated $\left(F_{4,12}=3.121, p>0.05\right.$ for the Flörsheim soil at week 8 and $F_{4,9}=2.724, p>0.05$ for the Amsterdam soil at week 16).

As with SIR, DHA values showed a similar response to the model chemical in the Bangor soil. Again carbendazim did not induce any significant effect at any of the sampling times, despite the more pronounced tendency to show lower values at the highest treatment levels. In some cases more than $20 \%$ inhibition occurred. However, the presentation of $\mathrm{EC}_{20}$ values is risky due to the absence of a clear dose-response relationship or to the high variability within treatments. In the Coimbra soil no significant differences occurred between chemical treatments and controls at any of the sampling times. The response was not constant through time, with an increase in activity with carbendazim dosage at week 1 and an inverse trend after 4 and 8 weeks, where more than $50 \%$ inhibition occurred at the two highest dose levels. However, the significant positive correlation with soil moisture content (Table 2) together with the absence of significant differences with the control, makes the calculation of the $\mathrm{EC}_{50}$ value unreliable. A similar situation was observed in the Flörsheim soil at week 8. However, in this case significant differences were found between the two highest concentrations and the control $\left(q_{13,5}=2.762\right.$, 
Table 2. Correlation values $(r)$ between microbial parameters and soil moisture content in TME pre-test, TME ring-test and field validation study

\begin{tabular}{|c|c|c|c|c|c|c|c|c|c|c|c|c|}
\hline & \multicolumn{3}{|c|}{ Amsterdam } & \multicolumn{3}{|c|}{ Bangor } & \multicolumn{3}{|c|}{ Coimbra } & \multicolumn{3}{|c|}{ Flörsheim } \\
\hline & $\begin{array}{l}\text { TME- } \\
\text { pre }\end{array}$ & $\begin{array}{l}\text { TME- } \\
\text { ring }\end{array}$ & Field & $\begin{array}{l}\text { TME- } \\
\text { pre }\end{array}$ & $\begin{array}{l}\text { TME- } \\
\text { ring }\end{array}$ & Field & $\begin{array}{l}\text { TME- } \\
\text { pre }\end{array}$ & $\begin{array}{l}\text { TME- } \\
\text { ring }\end{array}$ & Field & $\begin{array}{l}\text { TME- } \\
\text { pre }\end{array}$ & $\begin{array}{l}\text { TME- } \\
\text { ring }\end{array}$ & Field \\
\hline \multicolumn{13}{|c|}{ Substrate induced respiration $\left(\mathrm{mg} \mathrm{CO} \mathrm{CO}_{2} / \mathrm{g}\right.$ soil $\left.\mathrm{DW} / \mathrm{h}\right)$} \\
\hline Week 1 & $0.48^{*}$ & -0.22 & 0.102 & $0.82^{*}$ & 0.28 & -0.21 & $0.51^{*}$ & -0.02 & -0.02 & 0.14 & 0.54 & 0.39 \\
\hline Week 4 & $0.76^{*}$ & & & $0.73^{*}$ & & & -0.22 & & & $0.93^{*}$ & & \\
\hline Week 8 & 0.27 & 0.18 & 0.14 & $0.67^{*}$ & $0.72^{*}$ & 0.11 & $0.52^{*}$ & -0.33 & 0.22 & $0.90^{*}$ & -0.00 & 0.03 \\
\hline Week 16 & $0.86^{*}$ & 0.24 & 0.04 & $0.66^{*}$ & 0.38 & $0.40^{*}$ & 0.371 & 0.20 & -0.21 & $0.95^{*}$ & -0.06 & -0.13 \\
\hline \multicolumn{13}{|c|}{ Dehydrogenase activity (mg TPF/g soil DW/h) } \\
\hline Week 1 & 0.43 & -0.23 & 0.27 & 0.19 & $0.59^{*}$ & 0.05 & 0.06 & -0.30 & 0.34 & $0.52^{*}$ & 0.45 & $0.63^{*}$ \\
\hline Week 4 & $0.59^{*}$ & & & 0.43 & & & 0.37 & & & 0.1 & & \\
\hline Week 8 & 0.04 & 0.11 & 0.21 & 0.04 & 0.17 & -0.15 & $0.59^{*}$ & 0.20 & 0.18 & 0.55 & 0.15 & 0.18 \\
\hline Week 16 & $0.49^{*}$ & 0.38 & 0.10 & 0.13 & 0.26 & $0.41^{*}$ & -0.02 & 0.22 & 0.23 & 0.72 & 0.12 & 0.14 \\
\hline \multicolumn{13}{|c|}{ Phosphatase activity ( $m g \mathrm{pNP} / \mathrm{g}$ soil $\mathrm{DW} / \mathrm{h}$ ) } \\
\hline Week 1 & & 0.33 & 0.32 & & $0.82^{*}$ & 0.06 & & 0.38 & 0.11 & & 0.27 & 0.49 \\
\hline Week 8 & & $0.42^{*}$ & 0.07 & & $0.85^{*}$ & 0.34 & & 0.23 & $0.50^{*}$ & & $0.44^{*}$ & 0.01 \\
\hline Week 16 & & $0.45^{*}$ & 0.35 & & $0.66^{*}$ & 0.01 & & 0.15 & 0.32 & & 0.00 & 0.23 \\
\hline \multicolumn{13}{|c|}{ Thymidine incorporation (pmol $\left[{ }^{3} H\right] T / g$ soil $D W / h$ ) } \\
\hline Week 4 & 0.19 & & & 0.25 & & & -0.12 & & & NA & & \\
\hline Week 16 & 0.21 & -0.10 & 0.34 & 0.21 & $0.62^{*}$ & -0.09 & 0.30 & 0.15 & -0.16 & NA & 0.09 & 0.10 \\
\hline
\end{tabular}

NA - not available.

${ }^{*}$ Significant $(p<0.05)$ correlations.

$p<0.05$ for T3 and $q_{13,5}=2.936, p<0.05$ for T4). Still, the correlation with soil moisture content and the elimination of significant differences after performing the ANOVA using soil moisture content as a covariable $\left(F_{4,12}=2.195, p>0.05\right)$, do not allow the calculation of a reliable $\mathrm{EC}_{50}$ value. DHA in the Amsterdam soil was the parameter most affected by carbendazim, with significant differences compared to controls on weeks 8 and 16, even after correcting for the moisture effect with an ANOVA using soil moisture content as covariable $\left(F_{4,12}=3.344, p<0.05\right.$ for week 8 and $F_{4,12}=8.119, p<0.05$ for week 16). The effect of the model chemical increased from week 8 to week 16, with this last sampling time showing lower NOEC and $\mathrm{EC}_{50}$ values $\left(\mathrm{NOEC}_{(8 \text { weeks })}=\right.$ $12.96 \mathrm{~kg}$ a.i./ha; $\operatorname{NOEC}_{(16 \text { weeks })}=0.36 \mathrm{~kg}$ a.i./ha; $\mathrm{EC}_{50(8 \text { weeks })}=52.5 \mathrm{~kg}$ a.i. $/ \mathrm{ha}( \pm 13.2) ; \mathrm{EC}_{50 \text { (16 weeks) }}$ $=3.5 \mathrm{~kg}$ a.i. $/$ ha $( \pm 1.8))$.

The rates of thymidine incorporation found in this study were within the range quoted elsewhere (1-35 pmol thymidine $\mathrm{g}^{-1}$ dry wt. soil $\mathrm{h}^{-1}$; Bååth, 1992; Christensen, 1993; Christensen et al., 1995). The general trend in all soil types is an inhibition of this parameter by high dosages of carbendazim.
In Flörsheim soil a significant difference was obtained after 16 weeks, with the NOEC (16 weeks) being $12.96 \mathrm{~kg}$ a.i./ha. By contrast to the other microbial parameters, thymidine incorporation in the Bangor soil was the most affected parameter, with a significant decrease observed after both 4 and 16 weeks at the highest doses $\left(F_{4,7}=15.012\right.$, $p<0.05$ for week 4 and $F_{4,11}=10.005, p<0.05$ for week 16). NOEC values obtained at these two sampling times were 2.16 and $12.96 \mathrm{~kg}$ a.i./ha, respectively. Also more than $50 \%$ inhibition was found in both sampling times with $\mathrm{EC}_{50 \text { (4 weeks) }}$ $=12.2 \mathrm{~kg}$ a.i. $/ \mathrm{ha}( \pm 1.6)$ and $\mathrm{EC}_{50 \text { (16 weeks) }}=$ $34.6 \mathrm{~kg}$ a.i./ha $( \pm 14.2)$. Amsterdam soil showed a decrease at week 16 while in Coimbra soil no significant differences between treatment levels and controls were observed.

TME ring-test and field-validation study: comparison of control values and data variability

As in TME pre-test, control treatments of Flörsheim and Bangor soils have higher values of SIR and DHA than the Coimbra and Amsterdam soils, both in the TME ring-test $\left(F_{3,54}=852.17\right.$, 
$p<0.001$ for SIR and $F_{3,59}=207.01, p<0.001$ for DHA) and the field-validation study $\left(F_{3,58}=316.89, \quad p<0.001\right.$ for SIR and $F_{3,63}=133.72, p<0.001$ for DHA) (Table 3). Phosphatase activity showed the lowest values in the Coimbra soil while the Amsterdam soil showed the highest activity, closely followed by the Bangor and Flörsheim soils $\left(F_{3,63}=49.89, p<0.001\right.$ for TME and $F_{3,62}=75.56, p<0.001$ for field). Thymidine incorporation by bacteria showed significant differences between soils only in the TME ring-test, with Amsterdam soil detaching from the group and presenting lower incorporation rates $\left(F_{3,19}=3.50, p<0.05\right.$ for TME and $F_{3,19}=0.61$, $p>0.05$ for field).

When comparing control values between the TME ring-test and field-validation study at each sampling time (Table 3), results obtained for SIR showed significant differences only 1 week after chemical application in the Amsterdam $\left(t_{(6)}=6.71, \quad p<0.001\right)$, Bangor $\quad\left(t_{(6)}=2.90\right.$, $p<0.05)$ and Coimbra $\left(t_{(6)}=-2.96, p<0.05\right)$ soils. In the former two soils, the TME ring-test had higher values than the field-validation study, while in the latter soil the inverse occurred. More significant differences were found for DHA, particularly at weeks 8 and 16 , but never in the Flörsheim soil. Associated to these differences are, generally, higher average values in the field-validation study than in the TME ring-test. As for the phosphatase activity all but three comparisons showed significant differences between controls. With the exception of the Flörsheim soil, where all values found in the TMEs were lower than those obtained in the field, the tendency within each of the other soils was biased towards higher values in the TME controls. Contrary to the phosphatase activity, when the thymidine incorporation was considered, only one significant difference was found in the Amsterdam soil, with field control values being higher than those found on the TMEs.

The comparison of CVs obtained at each treatment level from both experiments (data not presented) revealed that only a few significant differences were found when analysing SIR data. In four of the five differences found, variability was higher among field values. For DHA, more

Table 3. Average control values (SD) for the microbial parameters measured during TME ring-test and field validation study

\begin{tabular}{|c|c|c|c|c|c|c|c|c|c|c|c|c|}
\hline & \multicolumn{3}{|c|}{ Amsterdam } & \multicolumn{3}{|l|}{ Bangor } & \multicolumn{3}{|l|}{ Coimbra } & \multicolumn{3}{|l|}{ Flörsheim } \\
\hline & TME & Field & $p$ & TME & Field & $p$ & TME & Field & $p$ & TME & Field & $p$ \\
\hline \multicolumn{13}{|c|}{ Substrate induced respiration $\left(\mathrm{mgCO}_{2} / \mathrm{g}\right.$ soil $\left.\mathrm{DW} / \mathrm{h}\right)$} \\
\hline Week 1 & $27.6(2.5)$ & $17.7(1.6)$ & $<0.001$ & $153.2(8.7)$ & $136.8(7.1)$ & $<0.05$ & $19.6(2.8)$ & 25.8 & $<0.05$ & $\begin{array}{l}107.5 \\
(10.9)\end{array}$ & $100.1(9.8)$ & n.s. \\
\hline Week 8 & $20.9(2.3)$ & $27.3(6.1)$ & n.s. & $\begin{array}{l}157.3 \\
(11.0)\end{array}$ & $153.2(9.3)$ & n.s. & $19.5(4.1)$ & $26.7(6.1)$ & n.s. & $101.9(8.4)$ & $96.0(4.4)$ & n.s. \\
\hline Week 16 & $25.4(5.9)$ & $33.8(4.8)$ & n.s. & $\begin{array}{l}153.1 \\
(14.0)\end{array}$ & $\begin{array}{l}157.6 \\
(22.3)\end{array}$ & n.s. & $21.0(4.2)$ & $18.5(3.3)$ & n.s. & $\begin{array}{l}102.2 \\
(11.7)\end{array}$ & $94.1(4.3)$ & n.s. \\
\hline \multicolumn{13}{|c|}{ Dehydrogenase activity (mg TPF/g soil $D W / h)$} \\
\hline Week 1 & $4.7(0.9)$ & $2.7(0.9)$ & $<0.01$ & $15.9(3.0)$ & $13.8(3.4)$ & n.s. & $4.2(0.5)$ & $3.4(2.2)$ & n.s. & $22.2(2.0)$ & $21.8(6.2)$ & n.s. \\
\hline Week 8 & $2.2(0.4)$ & $2.3(0.5)$ & n.s. & $12.1(2.5)$ & $18.6(1.2)$ & $<0.001$ & $1.5(0.3)$ & $3.3(1.0)$ & $<0.01$ & $27.1(2.8)$ & $25.3(3.9)$ & n.s. \\
\hline Week 16 & $2.1(0.9)$ & $6.1(0.6)$ & $<0.001$ & $11.9(2.0)$ & $10.7(1.6)$ & n.s. & $2.1(0.4)$ & $4.6(0.5)$ & $<0.001$ & $17.0(0.8)$ & $18.7(3.5)$ & n.s. \\
\hline \multicolumn{13}{|c|}{ Phosphatase activity ( $m g \mathrm{pNP} / \mathrm{g}$ soil $\mathrm{DW} / \mathrm{h}$ ) } \\
\hline Week 1 & $\begin{array}{l}103.3 \\
(4.4)\end{array}$ & $135.3(3.5)$ & $<0.001$ & $\begin{array}{l}130.7 \\
(14.2)\end{array}$ & $95.6(5.5)$ & $<0.001$ & $50.9(10.8)$ & $46.6(8.1)$ & n.s. & $60.3(7.7)$ & $97.5(3.8)$ & $<0.001$ \\
\hline Week 8 & $\begin{array}{l}127.3 \\
(11.7)\end{array}$ & $113.4(4.5)$ & n.s. & $104.0(4.5)$ & $83.6(6.0)$ & $<0.001$ & $74.2(3.3)$ & $44.4(7.2)$ & $<0.001$ & $96.4(2.4)$ & $124.0(7.5)$ & $<0.001$ \\
\hline Week 16 & $\begin{array}{l}109.9 \\
(9.8)\end{array}$ & $103.2(4.2)$ & n.s. & $99.9(7.2)$ & $136.7(6.4)$ & $<0.001$ & $49.3(3.7)$ & $40.2(3.8)$ & $<0.01$ & $89.5(1.5)$ & $111.0(8.6)$ & $<0.001$ \\
\hline \multicolumn{13}{|c|}{ Thymidine incorporation $\left(\mathrm{pmol}\left[{ }^{3} \mathrm{H}\right] \mathrm{T} / \mathrm{g}\right.$ soil $\mathrm{DW} / \mathrm{h}$ ) } \\
\hline Week 16 & $12.9(1.7)$ & $19.6(4.1)$ & $<0.01$ & $22.3(6.4)$ & $19.6(5.1)$ & n.s. & $18.9(6.0)$ & $17.8(8.7)$ & n.s. & $16.8(5.5)$ & $22.7(7.6)$ & n.s. \\
\hline
\end{tabular}

Samples were compared by a $t$-test. 
significant differences were found between $\mathrm{CVs}$ distributed among the four soils. In this case, however, no clear trend was observed, with both TME and field values showing a high variability (ranging between $1.0 \%$ and $60.2 \%$ ). Comparisons made for the phosphatase activity values revealed only a few significant differences. These were distributed among all soils. Similarly to what was observed with DHA, no clear tendency was observed in the variation in data from both the TME ring-test and the field-validation study. For thymidine incorporation, only one significant difference was found on Bangor soil. Analysing the magnitude of values in all parameters, phosphatase activity showed the lowest CV values $(0.2-$ $23.9 \%$ ), followed closely by SIR (0.6-38.2\%). By contrast, thymidine incorporation showed the highest CV values (6.6-77.9\%).

\section{TME ring-test and field-validation study: effects of} carbendazim

The model chemical had no effect on SIR in Flörsheim or Amsterdam soils at any of the sampling times during the TME ring-test (Fig. 1a-f). The absence of significant differences between treatment levels and controls was also observed on the field-validation study, despite the tendency of a reduced SIR at the highest carbendazim doses (Fig. 1a, b, d and e). In Bangor soil this tendency was generalized to both experiments throughout the study period (Fig. 1g-i). However significant differences were found only in the TME ring-test $\left(F_{2,9}=40.68, p<0.01\right.$ for week $1 ; F_{6,20}=4.79$, $p<0.05$ for week 8 and $F_{6,17}=3.66, p<0.05$ for week 16). NOEC calculations on weeks 8 and 16 may be questionable due to the strong correlation with soil moisture content (TME week 8 - see Table 2) or to the oscillating pattern of average values (week 16 - Fig. 1i). In Coimbra soil, carbendazim only exerted a significant effect at week 1 (Fig. 2j), both in the TMEs and the field $\left(F_{2,9}=10.59\right.$, $p<0.05$ for TME ring test and $F_{2,9}=7.63$, $p<0.05$ for field-validation study). This tendency of decreasing SIR with increasing carbendazim doses was also found in week 16 (Fig. 11), although more pronounced in the field-validation study.

In the Flörsheim and Amsterdam soils the effect of the chemical on DHA was similar to that ob- tained for SIR (Fig. 2a-f). In this case, however, a significant decrease in activity was found at the highest treatment level, 1 week after chemical application to the TME ring-tests in Flörsheim $\left(F_{2,10}=5.16, p<0.05\right)$ (Fig. 2a). In the Bangor soil, a decreased DHA was also observed at week 1 in both experiments. However, this difference was significant only in the TME ring-test $\left(F_{2,9}=5.19\right.$, $p<0.05$ ) (Fig. 2g). A significant decrease was also observed 16 weeks after chemical application in the TME ring-test. $\operatorname{NOEC}_{(16 \text { weeks-TME) }}$ was $3.24 \mathrm{~kg}$ a.i./ha. (Fig. 2i). The response obtained in the field-validation study at this sampling time was different, with a slight increase in DHA at the highest treatment levels. In the Coimbra soil, carbendazim also exerted a significant effect on DHA on week 1 in the TME ring-test $\left(F_{2,9}=\right.$ 36.05, $p<0.01$ ) (Fig. 2j). However, the response obtained at the other time points was different, with a significant recovery in activity after 8 weeks $\left(F_{6,20}=6.42, p<0.01\right)$ (Fig. $\left.2 \mathrm{k}\right)$ and a normalization of values after 16 weeks (Fig. 21). In this soil type, the model chemical induced a different response in the field-validation study. Here, the slight inhibition of DHA observed at week 1 was more pronounced towards the end of the study (Fig. 2j-1). After 16 weeks a significant decrease $\left(F_{6,17}=7.93, p<0.01\right)$ was observed allowing the estimation of a $\operatorname{NOEC}_{(16 \text { weeks-field })}$ of 1.08 $\mathrm{kg}$ a.i./ha.

The responses of phosphatase activity were different from those obtained on the former two parameters. In the field-validation study at Flörsheim, carbendazim caused a significant inhibition of phosphatase activity at week $1\left(F_{2,9}=6.06, p<\right.$ $0.05)$, followed by a recovery after 8 weeks $\left(F_{6,21}=3.85, p<0.05\right)$ (Fig. 3a and b) and a decrease after 16 weeks $\left(F_{6,20}=11.45, p<0.01\right)$ (Fig. 3c). The effects in the TME ring-test were visible only after 16 weeks $\left(F_{6,21}=18.49, p<\right.$ 0.01) (Fig. 3c). $\operatorname{NOEC}_{(16 \text { weeks-field) }}$ was $1.08 \mathrm{~kg}$ a.i./ha and $\operatorname{NOEC}_{(16 \text { weeks-TME) was } 3.24 \mathrm{~kg} \text { a.i./ }}$ ha. In the Amsterdam soil, with the exception of TME ring-test at week 1, the chemical induced a general, and in some cases significant, stimulation of phosphatase activity $\left(F_{6,20}=18.20, p<0.01\right.$ for the field-validation study at week 8 and $F_{6,19}=7.09, p<0.01$ for TME at week 16) (Fig. 3d-f). The pattern observed in the Bangor soil (Fig. 3g-i) was similar to the response ob- 
Week 1
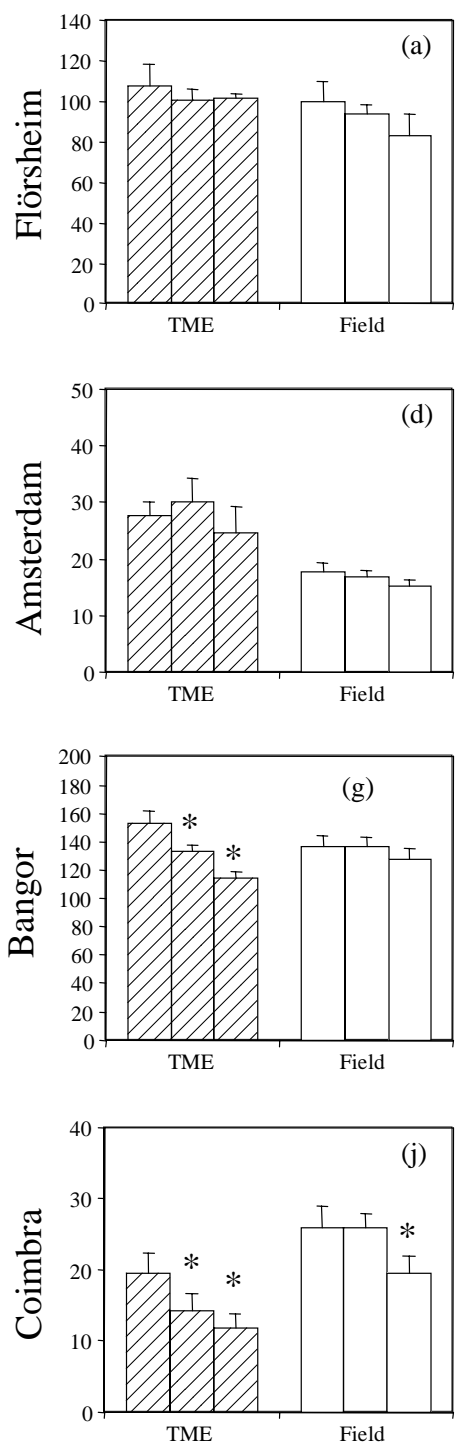

Week 8
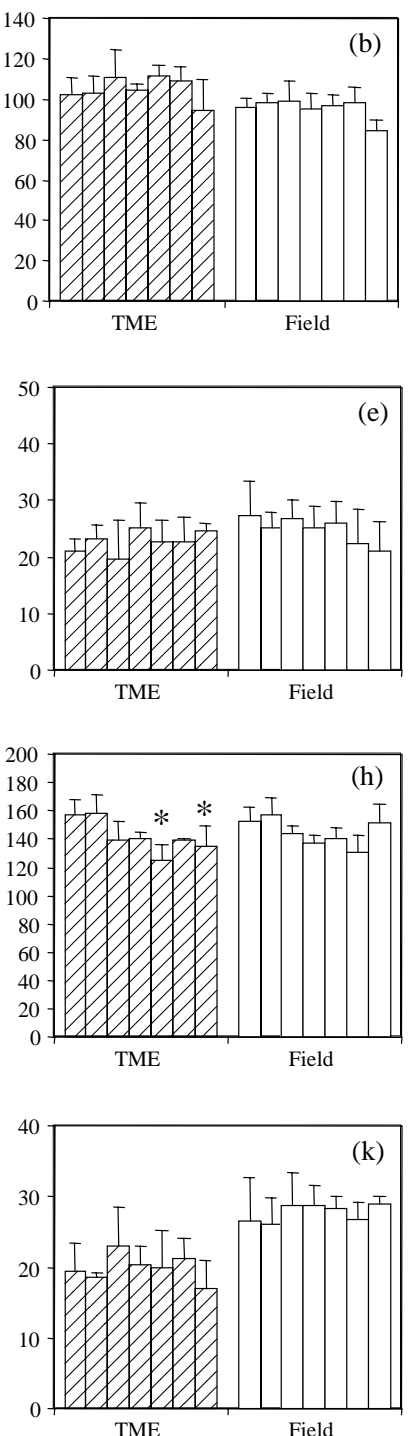

Week 16
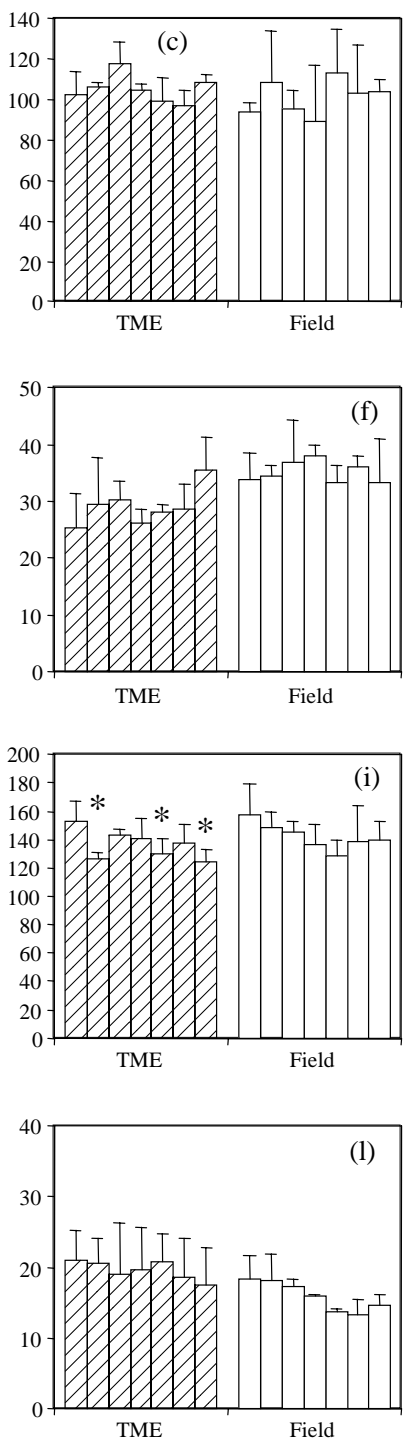

Figure 1. Effects of carbendazim on substrate induced respiration (average $\mu g \mathrm{CO}_{2} / \mathrm{g}$ soil DW/h $+\mathrm{SD}$ ) in the TME ring test (hatched bars) and field-validation study (open bars) on the four studied soils. At week 1 only three treatments were sampled (T0, T1 and T63 bars/experiment); at weeks 8 and 16 all treatments were sampled (T0-T6-7 bars/experiment). Carbendazim doses are: T0-control; T1-0.36 kg a.i./ha; T2-1.08 kg a.i./ha; T3-3.24 kg a.i./ha; T4-9.72 kg a.i./ha; T5-29.16 kg a.i./ha and T6-87.48 kg a.i./ha. Asterisks indicate significant differences in relation to control values after a Dunnett comparison test.

tained in Flörsheim. In the TME ring-test the small inhibition observed at week 1 increased until the end of the study $\left(F_{6,22}=3.85, p<0.01\right.$ for week 8 and $F_{6,22}=6.71, p<0.01$ for week 16$)$, allowing the calculation of a $\operatorname{NOEC}_{(8 \text { weeks-TME) }}=$ $3.24 \mathrm{~kg}$ a.i. $/$ ha and a $\operatorname{NOEC}_{(16 \text { weeks-TME })}=9.72$ $\mathrm{kg}$ a.i./ha. In the field-validation study a significant effect was observed only after 16 weeks $\left(F_{6,20}=\right.$ $16.38, p<0.01)$, presenting a $\operatorname{NOEC}_{(16 \text { weeks- }}$ field) $=1.08 \mathrm{~kg}$ a.i./ha. However, the results observed in the TME experiment on the two last sampling times should be analysed carefully due to the significant correlation of phosphatase values with soil moisture content (Table 2). In Coimbra 

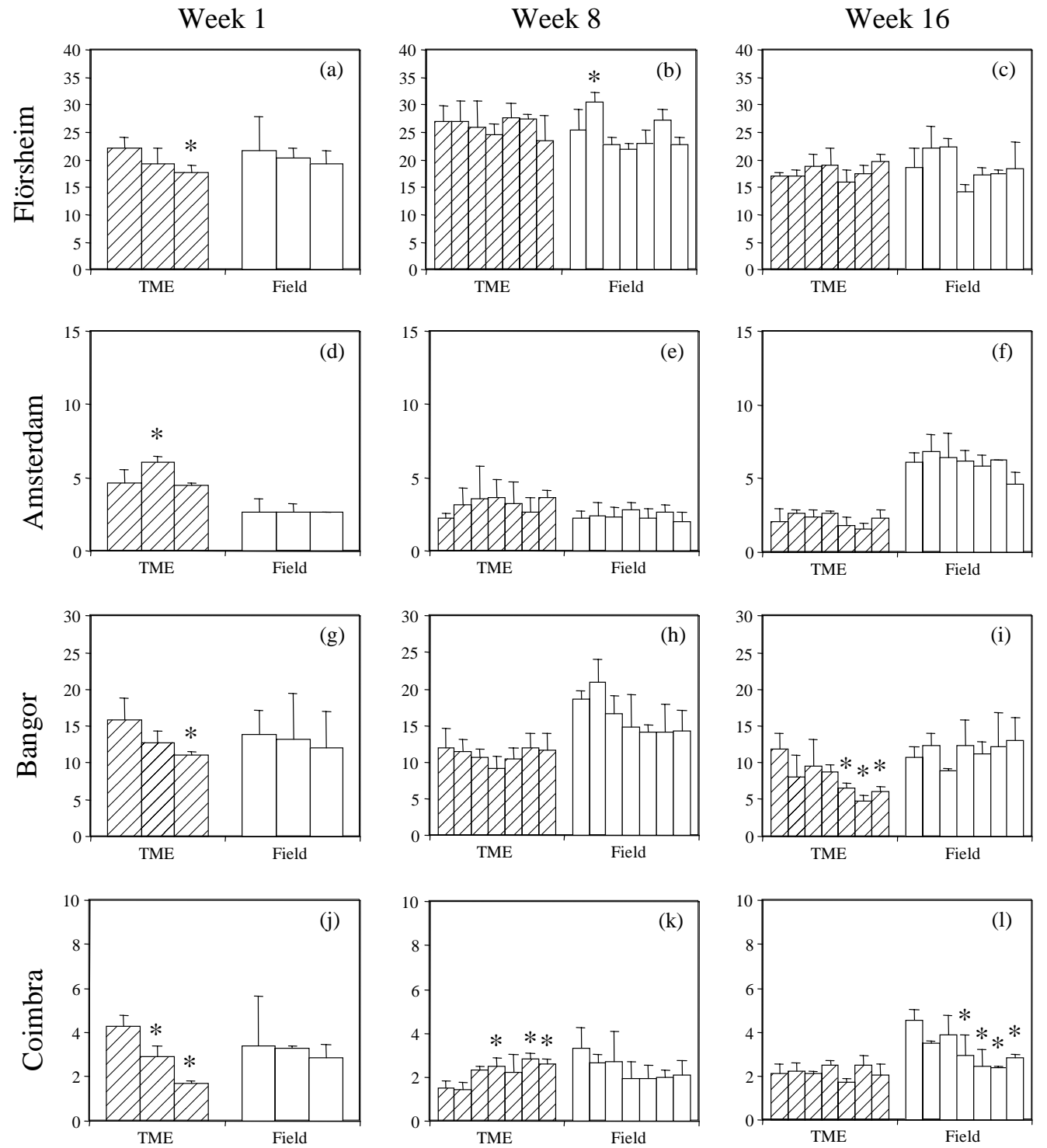

Figure 2. Effect of carbendazim on dehydrogenase activity (average $\mu \mathrm{g} \mathrm{TPF} / \mathrm{g}$ soil $\mathrm{DW} / \mathrm{h}+\mathrm{SD}$ ) in the TME ring test (hatched bars) and field-validation study (open bars) on the four studied soils. Bars and carbendazim dosages as in Fig. 1. Asterisks indicate significant differences in relation to control values after a Dunnet comparison test.

soil (Fig. 3j-1) the response obtained was similar, but a significant inhibition of phosphatase activity was obtained in the field-validation study at week $16\left(F_{6,21}=9.45, p<0.01\right)$. NOEC and $\mathrm{EC}_{20}$ values were 1.08 and $6.5 \mathrm{~kg}$ a.i./ha $( \pm 3.7)$ respectively. With the exception of Coimbra soil, and despite the significant effects reported above, inhibition of phosphatase activity in relation to control values never reached $20 \%$ in any of the soils.
Thymidine incorporation showed a tendency to decrease at the highest carbendazim dosage in all experiments (Fig. 4a-d). However, despite the high inhibition rate, due to the high variability of the results, significant differences with control values were only found in the Bangor $\left(F_{6,22}=\right.$ $3.43, p<0.05)$ and Flörsheim $\left(F_{6,23}=2.98\right.$, $p<0.05)$ field-validation studies and in the Coimbra $\left(F_{6,22}=5.14, p<0.01\right)$ TME ring-test, 

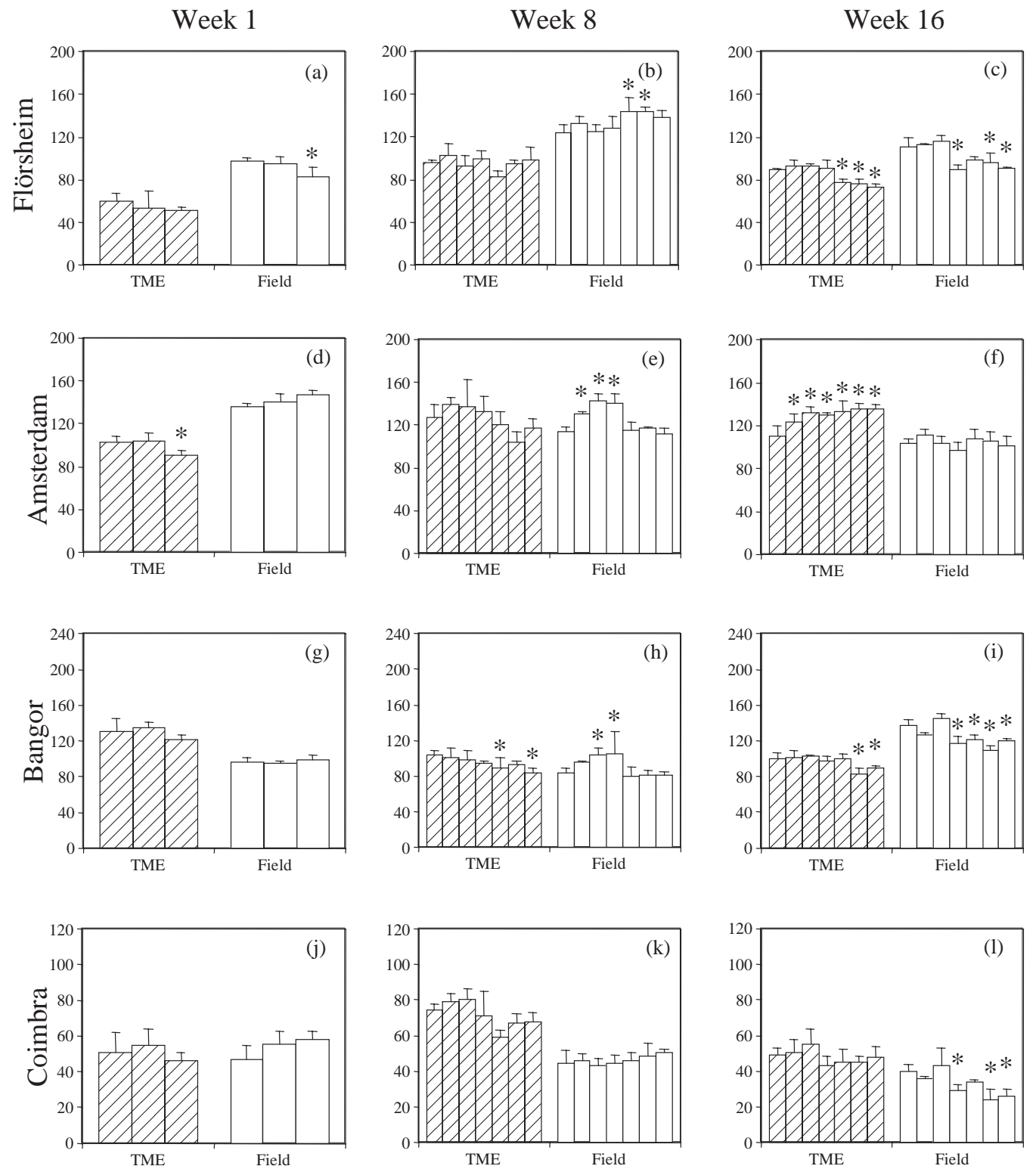

Figure 3. Effects of carbendazim on phosphatase activity (average $\mu \mathrm{g} p \mathrm{NP} / \mathrm{g}$ soil DW/h $+\mathrm{SD}$ ) in the TME ring test (hatched bars) and field-validation study (open bars) on the four studied soils. Bars and carbendazim dosages as in Fig. 1. Asterisks indicate significant differences in relation to control values after a Dunnett comparison test.

all having the same NOEC value of $29.16 \mathrm{~kg}$ a.i./ ha. $\mathrm{EC}_{50}$ calculations were also possible for these experiments; $\quad \mathrm{EC}_{50(16 \text { weeks-field })}=53.2 \mathrm{~kg}$ a.i. $/ \mathrm{ha}$ $( \pm 28.8)$ for Bangor, $\mathrm{EC}_{50(16 \text { weeks- }}$ field) $=51.2 \mathrm{~kg}$ a.i. $/$ ha $( \pm 39.4)$ for Flörsheim and $\mathrm{EC}_{50(16 \text { weeks }-\mathrm{TME})}=31.6 \mathrm{~kg}$ a.i. $/ \mathrm{ha} \quad( \pm 12.6)$ for Coimbra.

\section{Discussion}

TME pre-test

The response of the microbial parameters measured in the TME pre-test was generally highly correlated with soil moisture content (Table 2). 

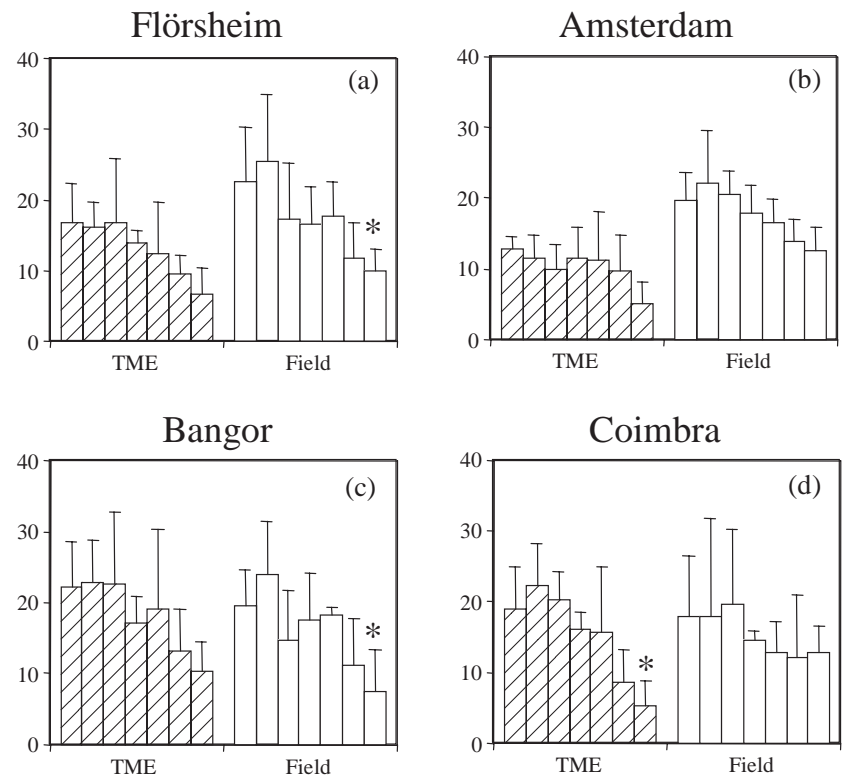

Figure 4. Effect of carbendazim on thymidine incorporation rate (average pmol $\left[{ }^{3} \mathrm{H}\right] \mathrm{T} / \mathrm{g}$ soil $\mathrm{DW} / \mathrm{h} \pm \mathrm{SD}$ ) in the TME ring test (hatched bars) and field-validation study (open bars) on the four studied soils 16 weeks after chemical application. Bars and carbendazim dosages as in Fig. 1. Asterisks indicate significant differences in relation to control values after a Dunnett comparison test.

This fact could have masked the effect of the model chemical. Where a significant decrease in SIR or DHA was observed, the strong correlation with soil moisture content could be responsible for the "apparent" dose-response relationships. With the exception of DHA in the Amsterdam soil 8 and 16 weeks after the chemical application, a "moisture effect" may have occurred. This enhances the importance of considering this parameter when analysing the results from microbial parameters in TME studies, and stresses the importance of a good control over soil moisture conditions during the performance of such experiments. Based on these results in the TME pre-test, the watering regime during the TME ring-test was changed, and so a more careful control of soil moisture conditions was exerted.

TME ring-test versus field-validation study: magnitude of values and data variability

When comparing control values of the TME ringtest and corresponding field-validation study, it is possible to see that with the exception of phosphatase activity, TME and field soils presented similar average values for the different microbial parameters measured. Small changes in soil properties may be the cause for differences observed. According to Acosta-Martinez and Tabatabai (2000), both acid and alkaline phosphatases are sensitive to changes in soil $\mathrm{pH}$. These authors found strong and significant correlations between both enzymes and this parameter. In any case, the different values observed in the different experiments, despite significant, were of the same order of magnitude.

Variability in the microbial parameters measured, as expressed by CVs, only rarely showed statistical differences between the TME ring-test and the field-validation study. This may indicate that TMEs can mimic the field spatial variability of these microbial parameters. It would be expected that the TME test by being conducted in a more standardized way would have shown a lower degree of variation when compared to the field. However this was not the case, with both the TME ring-test and the field-validation study presenting a higher $\mathrm{CV}$ depending on the case considered.

Analysing data variability between parameters, thymidine incorporation presented the highest $\mathrm{CV}$ 
values, most of them ranging from $20 \%$ to $60 \%$. Such a high variability was previously reported by Christensen et al. (1992). The variation found in the other three parameters is within the range of 8 $48 \%$ as indicated by Weyers and Schuphan (1998). In fact the range of CVs found in this study is, in some cases, much lower, with most of values ranging from $5 \%$ to $20 \%$, and also lower than the values found by Bonmati et al. (1991) for several biochemical parameters in the field. These authors found higher $\mathrm{CV}$ values for urease $(87.8 \%)$, protease $(30.5 \%)$ and phosphatase $(35.6 \%)$ activities than those observed here.

Parameter variability in TMEs can be the result of several factors. Besides natural variation or other biological factors not controlled by the researcher (e.g., species interactions), variation can originate from changes in experimental procedures that can be reduced in the future by controlling laboratory conditions (e.g., maintaining a constant soil moisture content and soil temperature), thus decreasing inter TME variation, and by using standard procedures to process soil samples and to measure the different parameters.

\section{TME ring-test versus field-validation study: effects of carbendazim}

Carbendazim only affected the measured microbial parameters at the highest treatment levels which in most cases correspond to more than 20 times the recommended field application rate of $0.36 \mathrm{~kg}$ a.i./ ha. As observed elsewhere, only high doses of pesticides were able to cause a significant decrease in microbial numbers, respiration or enzyme activity (Van Faassen, 1974; Dzantor and Felsot, 1991; Perucci and Scarponi, 1994; Perucci et al., 2000). Significant stimulatory effects and activity recovery were also found in this study for DHA and phosphatase activity. Similar effects on microbial activity have been reported by several authors (Peeples, 1974; Wainwright and Pugh, 1974; Harden et al., 1993) after the application of herbicides and fungicides. These can be explained by an enhanced activity of microorganisms in degrading the compounds by co-metabolic processes, especially after the amendment of organic material to treated soils (Felsot and Dzantor, 1995; Perucci et al., 2000). Data available on carbendazim showed that this chemical rarely induces any sig- nificant inhibition of soil microbial parameters, although the doses normally used were never as high as the ones used in the present study (Helweg, 1973; Adema et al., 1984; Li and Nelson, 1985; Förster et al., 1996; Hart and Brookes, 1996a), and this may explain the few significant inhibitory effects previously found.

Analysing each parameter individually and comparing the responses obtained in the TME ring-test and corresponding field-validation study, it is possible to see that effects on SIR were observed mainly 1 week after chemical application. The exception was Bangor soil, where significant decreases of SIR were observed in both the TME ring-test and the field-validation study after 8 and 16 weeks. However, these statistically significant effects could be considered a product of small changes in variability (Fig. $1 \mathrm{~h}$ and i) and may not have a strong ecological meaning. Therefore the results obtained in the field-validation study followed the same trend, despite the absence of significant differences. In general, the type of response observed for this parameter (either no effect or the tendency to decrease at high doses) was similar between the TME ring-test and fieldvalidation study.

Carbendazim also induced significant effects on DHA at week 1. These were observed only in the TME ring-test, although data from the field-validation study showed the same tendency. These effects were transient in both the Amsterdam and Flörsheim soils, but lasted till the end of the study in Bangor and Coimbra. In these latter two soils the response obtained after 16 weeks in both experiments was different. So, in the Bangor soil, the TME ring-test was more sensitive than the field-validation study, but the opposite was observed in the Coimbra soil. With the exception of these two cases, the overall analysis revealed a similar type of response between the two experiments.

Effects on phosphatase activity induced by carbendazim were different from those observed for the other parameters. Most significant effects were observed after 8 and 16 weeks, but not on week 1. This may agree with the nature of this enzyme; being an exo-enzyme, phosphatase can be active in the soil even after the destruction of microbial cells (Rossel et al., 1997), thus a possible effect on its activity could be found later in time. 
However, a significant inhibition of this enzyme 1 week after the application of carbendazim was observed in both Flörsheim and Amsterdam soils. In the former case the effect lasted until week 16, but in the latter case this effect was transient and a recovery could be observed further on. Prolonged inhibition of phosphatase by metalochlor was reported by Ismail et al. (1996), and transient effects of different insecticides on the activity of this enzyme were reported by several authors (Ismail et al., 1995; Tu, 1995). Comparing both experiments, phosphatase activity is the microbial parameter showing most differences in the responses induced by carbendazim. However, it is important to mention that some of these discrepancies may be "apparent", since in most cases the significant differences obtained between treatment levels and controls could be caused either by a strong correlation with soil moisture content (case of TME in Bangor soil - see Table 2), or by small changes in data variability. Moreover, the differences in relation to controls never reached $20 \%$ in the case of an inhibition, and rarely exceeded this value in the case of stimulation.

Carbendazim induced a similar response of thymidine incorporation by bacteria in all soils and in both the TME ring-test and the field-validation study. The inhibition of this parameter at high treatment levels may be due to slower bacterial growth rates or a smaller active bacterial population. The cause may not necessarily be direct toxicity of the pesticide, but may arise as a result of a disruption of nutrient supplies to the soil bacteria.

\section{The use of microbial parameters in TME studies}

When addressing the three questions raised earlier in the introduction, the overall analysis of the results produced in this study gives promising prospects for the use of TMEs in higher tier levels of risk assessment. Despite the differences between the TME ring-test and the corresponding fieldvalidation study, generally TMEs were able to show similar results on the selected microbial parameters in terms of magnitude, variability and response induced by the model chemical.

Regarding this last aspect, it is important to mention that the difficulty in estimating reliable endpoints (NOEC's and ECx's) was related both to the model chemical selected and to the measured effect parameters. The dose-response relationship obtained for microbial parameters does not always exhibit a sigmoid shape. Complex curves are common, mainly due to the strong heterogeneity of microorganisms producing the response to the chemical stressor (Welp and Brummer, 1997). A succession of "inhibitions", "stimulations" and "recoveries" or "no effects" may occur, making estimations difficult. Some of the curves observed in this study followed the mixture of patterns described by Welp and Brummer (1997).

Despite the above, the role of microbial parameters in microcosm/mesocosm studies cannot be neglected. Due to their ecological relevance in the soil system, effect parameters involving microorganisms should be included in these type of studies. However, special attention should be given to several aspects, not related to the chemical used, that may affect the outcome of the test. Firstly, the control of several abiotic conditions is crucial; the effect of soil moisture content was addressed here, but other parameters, not measured in this study, can be of similar importance. Secondly, the standardization of procedures to conduct the study and to estimate microbial parameters is essential to reduce variability and to allow for a comparison of results. Finally, one should consider the selection of microbial parameters to be measured. It is difficult to select a single representative and sensitive parameter. Depending on the chemical to be tested, and on the segment of the microbial activity affected by it, different parameters have different sensitivities (Domsch et al., 1983; Sinsabaugh, 1994). To overcome this problem, the measurement of several microbial parameters seems to be a possible solution. Evaluation of soil respiration, soil microbial biomass, different enzymes related to different soil processes (e.g., related to nitrogen transformations), and parameters able to detect changes in physiological status and composition of microbial communities (e.g., the BIOLOG GN or ECOPLATE methods) are suggested by several authors (Torstensson, 1993; Dighton, 1997; Pell et al., 1998; Fairbrother et al., 1999). Only by using an integrating approach it is possible to have a sound interpretation of pollution induced effects on soil microbial communities. 


\section{Acknowledgements}

The authors would like to acknowledge the following entities and persons: the EU for the financial support provided for the R\&TD project "The use of Terrestrial Model Ecosystems (TME) to assess environmental risks in ecosystems", (Contract No.: ENV4-CT97-0470); AgrEvo UK Ltd. for kindly providing the model chemical and analytical standards for carbendazim; Escola Superior Agrária de Coimbra, for allowing the realization of this study in Portugal; the students from the project "Ciência Viva" for helping during the sampling phase of this study. The authors also thank the Portuguese FCT - Fundação para a Ciência e Tecnologia, for providing a PhD grant to JMR and a MSc grant to SL.

\section{References}

Acosta-Martinez, V. and Tabatabai, M.A. (2000). Enzyme activities in a limed agricultural soil. Biol. Fertil. Soils 31, 8591.

Adema, D.M.M., Barug, D. and Vonk, J.W. (1984). Comparison of the effects of several chemicals on microorganisms, higher plants and earthworms. Symposium International sur L'Écotoxicologie Terrestre, Las Arcs (Savoie), pp. 199-211.

Bååth, E. (1992). Thymidine incorporation into macromolecules of bacteria extracted from soil by homogenizationcentrifugation. Soil Biol. Biochem. 24, 1157-65.

Beck, T., Öhlinger, R. and Baumgarten, A. (1996). Substrateinduced respiration. In: F. Schinner, R. Öhlinger, E. Kandeler and R. Margesin (eds). Methods in Soil Biology, pp. 64-8. Berlin: Springer-Verlag.

Bonmati, M., Ceccanti, B. and Nanniperi, P. (1991). Spatial variability of phosphatase, urease, protease, organic carbon and total nitrogen in soil. Soil Biol. Biochem. 23, 391-6.

Chalam, A.V., Sasikala, C., Ramana, C.V. and Rao, P.R. (1996). Effect of pesticides on hydrogen metabolism of Rhodobacter sphaeroides and Rhodopseudomonas palustris. FEMS Microbiol. Ecol. 19, 1-4.

Chiba, M., Bown, A.W. and Danic, D. (1987). Inhibition of yeast respiration and fermentation by benomyl, carbendazim, isocyanates, and other fungicidal chemicals. Can. J. Microbiol. 33, 157-61.

Christensen, H. (1993). Conversion factors for the thymidine incorporation technique estimated with bacteria in pure culture and on seedling roots. Soil Biol. Biochem. 25, 108596.

Christensen, H. and Christensen, S. (1995). [ $\left.{ }^{3} \mathrm{H}\right]$ Thymidine incorporation technique to determine soil bacterial growth rate. In A. Kassim and P. Nannipieri (eds). Methods in Applied Soil Microbiology and Biochemistry, pp. 258-61. Academic Press.
Christensen, H., Griffiths, B. and Christensen, S. (1992). Bacterial incorporation of tritiated thymidine and populations of bacteriophagous fauna in the rhizosphere of wheat. Soil Biol. Biochem. 24, 703-9.

Christensen, H., Rønn, R., Ekelund, F. and Christensen, S. (1995). Bacterial production determined by ${ }^{3} \mathrm{H}$-thymidine incorporation in field rhizospheres as evaluated by comparison to rhizodeposition. Soil Biol. Biochem. 27, 93-9.

Dick, R.P. (1997). Soil enzyme activities as integrative indicators of soil health. In C.E. Pankhurst, B.M. Doube and V.V.S.R. Gupta (eds). Biological Indicators of Soil Health, pp. 121-56. Wallingford: CAB International.

Dighton, J. (1997). Is it possible to develop microbial test systems to evaluate pollution effects on soil nutrient cycle? In N.M. Van Straalen and H. Løkke (eds). Ecological Risk Assessment of Contaminants in Soil, pp. 51-69. London: Chapman \& Hall.

Domsch, K.H., Jagnow, G. and Anderson, T.-H. (1983). An ecological concept for the assessment of side effects of agrochemicals on soil microorganisms. Res. Rev. 88, 66-105.

Dzantor, E.K. and Felsot, A.S. (1991). Microbial responses to large concentrations of herbicides in soil. Environ. Toxicol. Chem. 10, 649-55.

Eder, M., Knacker, T. and Römbke, J. (1992). Effects of pesticides on the decomposition process and the carboxymethylcellulase-activity in terrestrial ecosystems. In J.P.E. Anderson, D.J. Arnold, F. Lewis and L. Torstensson (eds). The International Symposium on Environmental Aspects of Pesticide Microbiology, pp. 74-8. Sweden; Sigtuna.

Fairbrother, A., Glazebrook, P.W., Van Straalen, N. and Tarazona, J. (1999). Summary of the SETAC Workshop on Test Methods for Hazard Determination of Metals and Sparingly Soluble Metal Compounds in Soils. 19-23 June 1999, San Lorenzo del Escorial, Spain. Pensacola, USA: SETAC Press.

Felsot, A.S. and Dzantor, E.K. (1995). Effect of alachlor concentration and an organic amendment on soil dehydrogenase activity and pesticide degradation rate. Environ. Toxicol. Chem. 14, 23-8.

Förster, B., Eder, M., Morgan, E. and Knacker, T. (1996). A microcosm study of the effects of chemical stress, earthworms and microorganisms and their interactions upon litter decomposition. Eur. J. Soil Biol. 32, 25-33.

Giller, K.E., Witter, E. and McGrath, S.P. (1998). Toxicity of heavy metals to microorganisms and microbial processes in agricultural soils: a review. Soil Biol. Biochem. 30, 1389-414.

Haanstra, L., Doelman, P. and Voshaar, J.H.O. (1985). The use of sigmoid dose response curves in soil ecotoxicological research. Plant Soil 84, 293-7.

Harden, T., Joergensen, R.G., Meyer, B. and Wolters, V. (1993). Soil microbial biomass estimated by fumigationextraction and substrate-induced respiration in two pesticide-treated soils. Soil Biol. Biochem. 25, 679-83.

Hart, M.R. and Brookes, P.C. (1996a). Effects of two ergosterol-inhibition fungicides on soil ergosterol and microbial biomass. Soil Biol. Biochem. 28, 885-92.

Hart, M.R. and Brookes, P.C. (1996b). Soil microbial biomass matter after 19 years of cumulative field applications of pesticides. Soil Biol. Biochem. 28, 1641-49. 
Heinemeyer, O., Insam, H., Kaiser, E.A. and Walenzik, G. (1989). Soil microbial biomass and respiration measurements: an automated technique based on infra-red gas analysis. Plant Soil 116, 191-5.

Helweg, A. (1973). Influence of the fungicide benomyl on microorganisms in soil. Tidsskrift for Planteavl 77, 375-84.

Ismail, B.S., Jokha, Y. and Omar, O. (1995). Effects of glucosinate-ammonium on microbial populations and enzyme activities in soils. Microbios 83, 185-90.

Ismail, B.S., Omar, O. and Ingon, D. (1996). Effects of metolachlor on the activities of four soil enzymes. Microbios 87, 239-48.

Kling, M. and Jakobsen, I. (1997). Direct application of carbendazim and propiconazole at field rates to the external mycelium of three arbuscular mycorrhizal fungi species: effect on 32P transport and succinate dehydrogenase activity. Mycorrhiza 7, 33-7.

Knacker, T., Van Gestel, C.A.M., Jones, S.E., Soares, A.M.V.M., Schallnaß, H.-J., Förster, B. and Edwards, C.A. (2004). Ring-testing and field-validation of a Terrestrial Model Ecosystem (TME) - an instrument for testing potentially harmful substances: conceptual approach and study design. Ecotoxicology 13, 9-27.

Kuhnt, G. and Muntau, H. (eds). (1994). EURO - Soils: Identification, Collection, Treatment, Characterization, pp. 1-144. Ispra, Italy: Joint Research Centre European Commission, Special Publication No. 1.94.60.

Li, C.Y. and Nelson, E.E. (1985). Persistence of benomyl and captan and their effects on microbial activity in field soils. Bull. Environ. Contam. Toxicol. 34, 533-40.

Margesin, R. (1996). Acid and alkaline phosphomonoesterase activity with the substrate $p$-nitrophenyl phosphate. In F. Schinner, R. Öhlinger, E. Kandeler and R. Margesin (eds). Methods in Soil Biology, pp. 213-7. Berlin: SpringerVerlag.

Megharaj, M., Singleton, I., Kookana, R. and Naidu, R. (1999). Persistence and effects of fenamiphos on native algal populations and enzymatic activities in soil. Soil Biol. Biochem. 31, 1549-53.

Morgan, E. and Knacker, T. (1994). The role of laboratory terrestrial model ecosystems in the testing of potentially harmful substances. Ecotoxicology 3, 213-33.

OECD (1984). OECD guidelines for testing of chemicals. Test guideline No. 208. Terrestrial plants, growth test. Organization for Economic Cooperation and Development, Paris.

Öhlinger, R. (1996). Dehydrogenase activity with the substrate TTC. In F. Schinner, R. Öhlinger, E. Kandeler and R. Margesin (eds). Methods in Soil Biology, pp. 241-3. Berlin: Springer-Verlag.

Peeples, J.L. (1974). Microbial activity in benomyl-treated soils. Phytopathology 64, 857-60.

Pell, M., Stenberg, B. and Torstensson, L. (1998). Potential denitrification and nitrification tests for evaluation of pesticide effects in soil. Ambio 27, 29-34.

Perucci, P. and Scarponi, L. (1994). Effects of the herbicide imazethapyr on soil microbial biomass and various soil enzyme activities. Biol. Fertil. Soils 17, 237-40.

Perucci, P., Dumontet, S., Bufo, S.A., Mazzatura, A. and Casucci, C. (2000). Effects of organic amendment and her- bicide treatment on soil microbial biomass. Biol. Fertil. Soils 32, 17-23.

Rossel, D., Tarradellas, J., Bitton, G. and Morel, J.-L. (1997). Use of enzymes in soil ecotoxicology: a case for dehydrogenase and hydrolytic enzymes. In J. Tarradellas, G. Bitton and D. Rossel (eds). Soil Ecotoxicology, pp. 179-206. Boca Raton: Lewis Publishers.

Schweiger, P.F. and Jakobsen, I. (1998). Dose-response relationships between four pesticides and phosphorus uptake by hyphae of arbuscular mycorrhizas. Soil Biol. Biochem. 30, 1415-22.

Sinsabaugh, R.L. (1994). Enzymatic analysis of microbial patterns and process. Biol. Fertil. Soils 17, 69-74.

Sparling, G.P. (1997). Soil microbial biomass activity and nutrient cycling as indicators of soil health. In C.E. Pankhurst, B.M. Doube and V.V.S.R. Gupta (eds). Biological Indicators of Soil Health, pp. 97-119. Wallingford: CAB International.

Stenberg, B., Johansson, M., Pell, M., Sjödahl-Svensson, K., Stenström, J. and Torstensson, L. (1998). Microbial biomass and activities in soil as affected by frozen and cold storage. Soil Biol. Biochem. 30, 393-402.

Torstensson, L. (1993). Ammonium oxidation, a rapid method to test chemical influence on nitrification in soil. Guideline 05. In L. Torstensson (ed.). Guidelines. Soil Biological Variables in Environmental Hazard Assessment, pp. 48-58. Solna, Sweden: Swedish Environmental Protection Agency, Report No. 4262.

Torstensson, L., Pell, M. and Stenberg, B. (1998). Need of a strategy for evaluation of arable soil quality. Ambio 27, 4-8.

Tu, C.M. (1995). Effect of 5 insecticides on microbial and enzymatic-activities in sandy soil. J. Environ. Sci. Health Part B-Pestic. Food Contam. Agric. Wast. 30, 289-306.

Van Faassen, H.G. (1974). Effect of the fungicide benomyl on some metabolic processess, and on numbers of bacteria and actinomycetes in the soil. Soil Biol. Biochem. 6, 131-3.

Velthorst, E.J. (1993). Manual for chemical water analysis. Department of Soil Science and Geology, Agricultural University, Wageningen, The Netherlands.

Vink, K. and Van Straalen, N.M. (1999). Effects of benomyl and diazinon on isopod-mediated leaf litter decomposition in microcosms. Pedobiologia 43, 345-59.

Wainwright, M. and Pugh, G.J. (1974). The effects of fungicides on certain chemical and microbial properties of soils. Soil Biol. Biochem. 6, 263-7.

Welp, G. and Brummer, G.W. (1997). Toxicity of increased amounts of chemicals and the dose-response curves for heterogeneous microbial populations in soil. Ecotoxicol. Environ. Safety 37, 37-44.

Weyers, A. and Schuphan, I. (1998). Variation of effect endpoint parameters in a terrestrial model ecosystem. Ecotoxicology 7, 335-41.

Weyers, A., Sokull-Klüttgen, B., Knacker, T., Martin, S. and Van Gestel, C.A.M. (2004). Use of terrestrial model ecosystem data in environmental risk assessment for industrial chemicals, biocides and plant protection products in the EU. Ecotoxicology 13, 163-176.

Zar, J.H. (1996). Biostatistical Analysis, 3rd edn. London: Prentice-Hall International. 